\title{
Solid State Fermentation of Carinata (Brassica carinata) Meal Using Various Fungal Strains to Produce a Protein-Rich Product for Feed Application
}

Jessika J. Simon, Stephanie A. Wootton, Tylor J. Johnson, Bishnu Karki, Jacob D. Zahler, Emily L. Baldwin, Mark Berhow, Jason R. Croat, and William R. Gibbons

${ }^{1}$ Department of Biology and Microbiology, South Dakota State University, Brookings, USA

${ }^{2}$ Department of Microbiology, The University of Tennessee, Knoxville, USA

${ }^{3}$ Department of Agriculture, National Center for Agricultural Utilization Research, Peoria, USA

\begin{abstract}
In this study, the efficacy of several fungal strains to reduce GLS (GLS) content and enhance protein content during solid state fermentation (SSF) of carinata meal was evaluated. Solid state fermentation of hexane extracted $(\mathrm{HE})$ and cold pressed (CP) carinata meals were performed at $50 \%$ moisture content at $30^{\circ} \mathrm{C}$ for $168 \mathrm{~h}$. The fungal strains evaluated in this study preferred HE carinata meal compared to CP meal due to the low level of residual oil in the HE meal. Among the various fungal strains evaluated, Neurospora crassa NRRL-2332 was found to be the preferred strain, with a maximal relative increase in protein content of $17.3 \%$ and $15.2 \%$, for $\mathrm{HE}$ and CP carinata meal, respectively. Solid state fermentation of HE carinata meal by $N$. crassa yielded an end-point protein content of $\sim 50 \%$, (db). This process also resulted in the complete reduction of GLS in HE and CP meals $(0 \mathrm{mg} / \mathrm{g} \mathrm{GLS})$. Of all the treatments evaluated in this study, SSF of HE carinata meal by $N$. crassa is preferred. Utilizing this treatment for carinata meal led to the formation of a protein-enriched product with no residual GLS content that has great potential for feed application.
\end{abstract}

Keywords: Animal feed; Digestibility; GLSs; Neurospora crassa; Protein-rich product

\begin{abstract}
Abbreviations
AACC: American Association for Clinical Chemistry; ANOVA: Analysis of Variance; CP: Cold Pressed; DB: Dry Basis; ESI: Electrospray Ionization; GLS: GLS; GYE: Glucose Yeast Extract; HE: Hexane Extracted; HPLC: High Performance Liquid Chromatography; LC-MS: Liquid Chromatography-Mass Spectrometry; MS: Mass Spectrometer; PDA: Potato Dextrose Agar; Q-TOF: Quadrupole Time-of-Flight; RP-HPLC: Reversed-Phase High Performance Liquid Chromatography; SINIG: Sinigrin; SSF: Solid State Fermentation; TBS: Tetrabutylammonium Bisulfate
\end{abstract}

\section{Introduction}

The ever-increasing global population and the consequential burden placed on the food supply necessitate renewable and sustainable sources of protein in food sources. Thus, there is a considerable amount of research currently being conducted to develop sustainable solutions for high-protein products from renewable resources. For example, patents have recently been filed for a process creating protein concentrate from canola meal and for SSF processes for producing protein concentrates from renewable resources [1,2]. Brassica carinata is a domestic plant commonly grown in the Ethiopian highlands, Spain, California and Italy, that can be cultivated in a rotation with cash crops to enhance agricultural sustainability by diversifying crop rotations, which disrupts pest and weed cycles [3]. B. carinata has also been established as a drought and heat tolerant oilseed crop in Canada [4]. The oil extracted from $B$. carinata can be utilized as vegetable oil. Additionally, these oils can be converted into jet fuel and biodiesel via existing technologies $[3,5]$.

Following oil extraction, the residual defatted meal could be used as a protein source for nutritional applications. The protein-rich defatted meal cannot be used for human nutrition, as it contains a high level of cellulose, phytates, and GLSs (GLS), which are considered antinutritional components [5]. The defatted meal is generally used as an organic fertilizer or animal feed, due to the anti-nutritional components previously mentioned. One strategy to increase the nutritional value of feedstocks containing high levels of GLS is to utilize a fungal fermentation process to increase the protein yield at a low cost [6]. Some fungal strains can also metabolize anti-nutritional factors into singlecelled proteins (edible microbes with a high nutritional value) [7].

One group of anti-nutritional chemicals present in defatted carinata meal is GLSs. GLSs are secondary metabolites that occur in all Brassicaoriginated feeds and fodders, and provide protection against insects, animals, and disease [8]. Approximately 120 different GLS have been identified, and all contain a $B$-D-thioglucose group, a sulphonated oxime moiety, and a variable side-chain derived from methionine, tryptophan, or phenylalanine $[8,9]$. GLS are stored in plant tissues, and when these tissues are disrupted, glucose is cleaved from GLS by myrosinase, which is then converted into nitriles, thiocyanates and isothiocyantaes [10]. The content and composition of GLS varies based on plant species, agronomic practices, and climatic conditions [8]. GLS ingestion by animals leads to several deleterious effects: reduced palatability, decreased growth, and decreased production [8]. These toxic effects occur when the compounds are consumed in high doses, thus, feed containing GLS have a reduced economic value [11]. The toxic effect from GLS is dependent on the animal that ingests the chemical. GLS ingestion in poultry increases mortality, and decreases egg production and weight [8]. GLS ingestion can be fatal to pigs; and cause deleterious

*Corresponding author: Tylor J. Johnson, Department of Microbiology, The University of Tennessee, Knoxville, USA, Tel: 3194713362; E-mail: tjohn141@ utk.edu

Received February 12, 2017; Accepted March 09, 2017; Published March 16, 2017

Citation: JJ Simon, SA Wootton, TJ Johnson, B Karki, JD Zahler, et al. (2017) Solid State Fermentation of Carinata (Brassica carinata) Meal Using Various Fungal Strains to Produce a Protein-Rich Product for Feed Application. J Microb Biochem Technol 9:577-582. doi: 10.4172/1948-5948.1000344

Copyright: @ 2017 JJ Simon, et al. This is an open-access article distributed under the terms of the Creative Commons Attribution License, which permits unrestricted use, distribution, and reproduction in any medium, provided the original author and source are credited. 
Citation: JJ Simon, SA Wootton, TJ Johnson, B Karki, JD Zahler, et al. (2017) Solid State Fermentation of Carinata (Brassica carinata) Meal Using Various Fungal Strains to Produce a Protein-Rich Product for Feed Application. J Microb Biochem Technol 9:577-582. doi: 10.4172/19485948.1000344

effects on growth function and thyroid function of fish $[8,10,12]$.

While there has not been much research conducted on carinata for feed application, oilseeds similar to carinata (i.e., camelina and canola) have been investigated. Previously, camelina meal was investigated for its nutritional value for beef cattle. It was determined the oilseeds could be used as a substitute for some protein-rich feedstuffs which are present in ruminant provisions [13]. Our research group previously utilized various fungal strains to increase the protein content of canola meal and evaluated the oilseed's potential as an animal feed [9]. In that study, it was determined that cold-pressed (CP) canola meal fermented by Trichoderma reesei NRRL 3653 was the preferred treatment. The protein content of the meal in these trials increased from $36.1 \%$ to $44.4 \%$ in hexane extracted (HE) meal and $38.6 \%$ to $47.5 \%$ in $\mathrm{CP}$ meal. This treatment also led to a decrease in GLS content, from 60.6 $\mu \mathrm{M} / \mathrm{g}$ to $1.0 \mu \mathrm{M} / \mathrm{g}$. In that study, the fungal strains metabolized GLS and other products into non-toxic compounds $\left(\mathrm{CO}_{2}, \mathrm{H}_{2} \mathrm{O}\right)$, which increased the nutritional value of the canola meal and created a more digestible product [10]. This study showed that certain fungal strains can convert carbohydrates and fiber from canola meal into protein-rich biomass, while also degrading GLS via fungal metabolism or thermal degradation [10]. The similarities between canola meal and carinata meal led us to hypothesize that the fungal strains used in that study could also be utilized to increase the nutritional value of carinata meal.

Typically, fermentations take place either in submerged or solid state environments. Solid state fermentations have been used commonly to produce animal feed and enzymes. In a previous study, numerous substrates (agro-industrial residues) and microorganisms (yeast, bacteria and fungi) were used to evaluate microbial enzyme production from SSFs [14]. Multiple fungal strains have also been used to determine the number of industrial enzymes that can be produced via SSF [14]. There are several advantages of using SSFs compared to submerged fermentations. Solid state fermentations replicate the natural environment that fungi can more readily adapt to $[15,16]$. Solid state fermentations also have a reduced water activity, have lower drying costs, and typically smaller incubation vessels are used, which reduces industrial processing costs $[10,17]$. Thus, the purpose of this study was to: 1) evaluate the ability of several fungal strains to produce a protein-rich product from carinata meal utilizing SSF fermentations, and 2) determine if these fermentations lead to a decrease in the antinutritional compounds, GLS.

\section{Materials and Methods}

\section{Feedstocks}

In this study, two types of carinata meals were used: 1) hexane extracted (HE) provided by Agrisoma BioSciences (Ottawa, Ontario, Canada) and 2) cold pressed (CP) obtained from Dakota Lakes Research Farm (Pierre, SD, USA). Prior to use, both meals were ground to a size of $2 \mathrm{~mm}$ (sieve size) via knife mill (FitzMill model \# S-DAS06, Elmhurst, IL, USA) and were stored in a sealed bucket at room temperature.

\section{Cultures and inoculum preparation}

The fungal strains used in this study were provided by the USDA National Center for Agricultural Utilization Research (Peoria, IL, USA) or were contaminants isolated by our research group in previous studies (Table 1). For long-term maintenance, strains were stored on potato dextrose agar (PDA) plates and stored at $4^{\circ} \mathrm{C}$. To inoculate seed cultures, square sections of PDA containing the fungal strains were removed with a sterile inoculating loop and transferred to 250 $\mathrm{ml}$ Erlenmeyer flasks containing $100 \mathrm{ml}$ of sterile glucose yeast extract

\begin{tabular}{|l|c|c|}
\hline Organism & Strain & pH \\
\hline Aureobasidium pullulans & NRRL-58522 & 3.0 \\
\hline Aureobasidium pullulans & NRRL-Y-2311-1 & 3.0 \\
\hline Trichoderma reesei & NRRL-3653 & 5.0 \\
\hline Fusarium venenatum & NRRL-26139 & 5.0 \\
\hline Paecilomyces variotti & NRRL-1115 & 4.5 \\
\hline Rhizopus microspores var. oligosporus & NRRL-2710 & 4.5 \\
\hline Neurospora crassa & NRRL-2332 & 5.0 \\
\hline Mucor circinelloides* & N/A & 5.0 \\
\hline Pichia kudriavzeii & N/A & 3.0 \\
\hline
\end{tabular}

Table 1: List of fungal strains and optimal ph of the growth media.

*These organisms were contaminants isolated from prior research and identified via 15s RNA analysis [29]

(GYE) (5\% glucose and $0.5 \%$ yeast extract) and incubated at $30^{\circ} \mathrm{C}$ at $150 \mathrm{rpm}$ for $\sim 72 \mathrm{~h}$. Flasks were stoppered with a foam stopper and covered in aluminum foil. Growth media for each culture was adjusted to an optimal $\mathrm{pH}$ (Table 1 ) by using $10 \mathrm{M}$ sulfuric acid or $10 \mathrm{M}$ sodium hydroxide prior to inoculation.

\section{Solid state fermentation of cold-pressed and hexane extracted carinata meal}

SSFs of CP and HE canola meal were conducted in $500 \mathrm{ml}$ Erlenmeyer flasks containing $100 \mathrm{~g}$ canola meal. The initial moisture content of CP and HE meals was $6.66 \%$ and $7.94 \%$, respectively. Both meals were adjusted to a final moisture content of $50 \%$ by adding water, and the $\mathrm{pH}$ was adjusted to optimal conditions for each organism by adding either sulfuric acid $(10 \mathrm{~N})$ or sodium hydroxide $(10 \mathrm{M})$. Flasks were then stoppered with foam plugs and autoclaved at $121^{\circ} \mathrm{C}$ for 40 min. Once cooled to room temperature, flasks were inoculated with 5 $\mathrm{ml}$ of the seed cultures and incubated static at $30^{\circ} \mathrm{C}$ for $168 \mathrm{~h}$. Visual observations of physical characteristics were recorded daily. After $168 \mathrm{~h}$ of fermentation, final $\mathrm{pH}$ was recorded and samples were recovered for further analysis. Solids were dried at $80^{\circ} \mathrm{C}$ for $48 \mathrm{~h}$ in a convection oven and were stored at room temperature for future protein, moisture, sugar, and GLS determination. All of the trials in the study were performed in triplicate.

\section{Analytical methods}

Moisture content: The moisture content of the carinata meal was determined using the American Association for Clinical Chemistry (AACC) method by drying $\sim 1 \mathrm{~g}$ sample at $80^{\circ} \mathrm{C}$ for $24 \mathrm{~h}$ in a hot air oven [18]

Protein measurement: The following methodology was adapted from Croat et al. [19]. The total protein content of dried samples was analyzed using a LECO model FP 528 (LECO Corp., St. Joseph, MI, USA), which combusted the samples and measured the total nitrogen gas content in the sample (AOCS Method 990.03). Approximately 0.25 $\mathrm{g}$ of a dried sample was placed in tin foil cups and was combusted to measure the total nitrogen content of the sample. Protein percentage was then calculated from the nitrogen content of the combusted sample using a conversion factor of 6.25 .

GLS determination: For GLS standards analysis, a freshly prepared sinigrin (SINIG) standard (Sigma-Aldrich Corp., St. Louis, MO, USA) was prepared on a molar concentration basis. Serial dilutions were prepared to make a standard curve and to determine the lower detection limit. GLS concentrations in these standards were determined via a SINIG calibration curve on an $\mathrm{nM} / \mathrm{mAbs}$ basis. Concentrations of carinata GLS in the samples were calculated from a standard curve 
of freshly prepared SINIG on a nanomoles injected basis. A standard curve prepared from serial dilutions of pure glucocamelinin was also used.

For high performance liquid chromatography (HPLC) analysis, $0.25-0.50 \mathrm{~g}$ of ground defatted canola meal was placed in a capped vial with $2-5 \mathrm{ml}$ methanol. The vials were sonicated for $15 \mathrm{~min}$ and then incubated at room temperature static overnight. The samples were again sonicated briefly and a portion of this extract was filtered through a $0.45 \mu \mathrm{M}$ filter into an auto-sampler vial. For GLS quantification, a modification of an HPLC method developed by Betz and Fox was used [20]. The extract was run on a Shimadzu (Columbia, MD, USA) HPLC system (two LC 20AD pumps; SIL 20A autoinjector; DGU 20As degasser; SPD-20A UV-VIS detector, CBM-20A communication BUS module) running under the Shimadzu LCsolutions Version 1.25 software. The column was a $\mathrm{C}_{18}$ Insertsil reverse phase column $(250$ $\mathrm{mm} \times 4.6 \mathrm{~mm}$; RP C-18, ODS-3, $5 \mathrm{u}$ with a Metaguard guard column) (Torrance, CA, USA). GLS were detected via monitoring at $237 \mathrm{~nm}$. For canola GLS analysis, the initial mobile phase conditions were $40 \%$ methanol $/ 60 \% 0.005 \mathrm{M}$ aqueous tetrabutylammonium bisulfate (TBS) at a flow rate of $1 \mathrm{ml} / \mathrm{min}$. After injection of $15 \mu \mathrm{l}$ sample, the initial conditions were held for $2 \mathrm{~min}$, and then developed up to $35 \%$ methanol over $20 \mathrm{~min}$, then up to $50 \%$ methanol over another $20 \mathrm{~min}$ and finally up $100 \%$ over another $10 \mathrm{~min}$.

GLS content of the samples were also analyzed according to the methodology of Berhow et al. [21]. Samples were run on a LTQ-XL Orbitrap MS (a linear ion trap), coupled to a high precision electrostatic ion trap mass spectrometer (MS) (LTQ XL, Thermo Scientific, Waltham, MA, USA) with an Ion Max electrospray ionization (ESI) source, coupled to an ACELLA series HPLC (ACELLA 1250 UHPLCS pump, ACCELA1 HTC cool stack auto-injector, and an ACELLA 80 $\mathrm{Hz}$ photodiode array detector) (Thermo Scientific). These instruments were operated under Thermo Scientific Xcalibur 2.1.0.1140 LCMS software. The MS was calibrated at least weekly with a standard calibration mixture recommended by Thermo Scientific and the signal detection was optimized by running the auto-tune software as needed. The MS was run with the ESI probe in the negative mode. The source inlet temperature was $300^{\circ} \mathrm{C}$, the sheath gas rate was set at 50 arbitrary units, the auxiliary gas rate was set at 3 arbitrary units, and the sweep gas rate was set at 2 arbitrary units. The maximal mass resolution was set at 30,000 , the spray voltage was set at $3.0 \mathrm{kV}$ and the tube lens was set at $-100 \mathrm{~V}$. Other parameters were determined and set by the calibration and tuning process of the instrument. The column used was a $3 \mathrm{~mm} \times$ $150 \mathrm{~mm}$ Inertsil reverse phase C-18, ODS 3, $3 \mu$ column (GL Sciences, Torrance, CA, USA). The initial solvent system was either $15 \%$ or $40 \%$ methanol and $80 \%$ or $60 \%$ water with $0.25 \%$ formic acid at a flow rate of $0.25 \mathrm{ml} / \mathrm{min}$. After injection $(1 \mu \mathrm{l})$, the column was held at the initial conditions for $5 \mathrm{~min}$, then developed with a linear gradient to $100 \%$ methanol over 60 additional min. The column effluent was monitored at $237 \mathrm{~nm}$ in the photodiode array detector.

\section{Statistical analyses}

To determine if statistical differences existed among the treatments (fungal strains and pretreatment methods), one-way analysis of variances (ANOVAs) was performed using the $\mathrm{R}$ statistical software program and the 'agricolae' package [22,23]. If significant differences were detected among the treatment means $(\alpha=0.05)$, then a Tukey's test was performed. The Tukey's test determined among which treatments the statistical differences occurred. One-way ANOVAs were used to evaluate protein content and GLS of the treatments in this study. All the trials performed in this study were performed in triplicate.

\section{Results and Discussion}

\section{Solid state fermentation of cold-pressed and hexane extracted carinata meal}

In this study, the efficacy of several fungal strains to produce protein-rich products from carinata meal via SSF was evaluated. In addition, the effect of these fermentations on the GLS content of the meal was elucidated via GC-MS (Figure 1). The filamentous fungi Trichoderma reesei ((NRRL-3653), Fusarium venenatum (NRRL26139), Mucor circinelloides, Aureobasidium pullulan (NRRL-58522) and Aureobasidium pullulans (NRRL-Y-2311-1) were chosen for this study due to their ability to produce cellulose degrading enzymes [10]. The yeast Pichia kudriavzevii was also evaluated in this study due to the strain's potential probiotic effect [10] (Figure 2).

Figure $2 \mathrm{~A}$ shows a comparison of the end-point total protein content [\%, dry basis $(\mathrm{db})]$ and Figure $2 \mathrm{~B}$ shows a comparison of the change in protein (\%) during the fermentation for each combination of fungal strain and meal type (HE vs. CP) evaluated in this study. In these figures, different lower case annotate that a statistically significant difference was detected among the means using a Tukey's test. All SSFs of HE carinata meal had significantly higher protein content than any SSF of CP carinata meal, regardless of the fungal strain utilized in the fermentation.

The composition of the HE and CP meal used in this study, prior to fungal fermentation, varied in terms of the protein and residual oil content. Total protein contents of HE and CP carinata meal were 41.92 and $35.38 \%(\mathrm{db})$, respectively. Residual oil content of the CP meal $(\sim 20 \%, \mathrm{db})$ was substantially higher than the HE meal $[1-2 \%,(\mathrm{db})]$. After fungal fermentation, the average protein content of HE carinata meal ranged from $\sim 44-50 \%(\mathrm{db})$ depending on the fungal strain utilized. The mean protein content of fermented CP carinata meal ranged from $[\sim 35-40 \%(\mathrm{db})]$ and the protein content in these trials increased $\sim 14 \%$. The relatively poor performance of the fungal fermentation in CP meal compared to HE meal may be due to the presence of high levels of the residual oil in CP meal. It is known that high concentrations of oil can be inhibitory to microbial growth [24].

Among the various fungal strains evaluated during HE meal fermentations, $N$. crassa and $P$. variotti resulted in the highest protein content of the strains evaluated $[\sim 50 \%,(\mathrm{db})]$. These strains led to a $17 \%,(\mathrm{db})$ increase in total protein content. T. reese $i$ had the next highest increase in protein content $[13 \%,(\mathrm{db})]$. Of the CP treatments evaluated, $N$. crassa yielded significantly more total protein and had a higher percent change in protein than all other $\mathrm{CP}$ treatments evaluated in this study. Although the fungal metabolism of solid substrates is dependent on various factors, it is well established that the microbial conversion process depends largely on the number of hydrolytic enzymes released by the fungal strains during the fermentation process [25]. Therefore, the increase in protein content of the fermented meal in this study can likely be attributed to the fungal conversion of oligosaccharides and fiber into cell mass. Although there are several reports available on the fungal conversion of soybean and canola meals using Aspergillus, Trichoderma, Rhizopus and other microbial genera,... to the best of our knowledge, this study is the first to evaluate the fungal metabolism of carinata meal to maximize its utilization for feed application [25]. These results provide evidence that of all the treatments evaluated in this study, HE carinata meal is the preferred substrate and N. crassa is the preferred fungal strain to utilize for solid-state fungal fermentations 
Citation: JJ Simon, SA Wootton, TJ Johnson, B Karki, JD Zahler, et al. (2017) Solid State Fermentation of Carinata (Brassica carinata) Meal Using Various Fungal Strains to Produce a Protein-Rich Product for Feed Application. J Microb Biochem Technol 9:577-582. doi: 10.4172/19485948.1000344

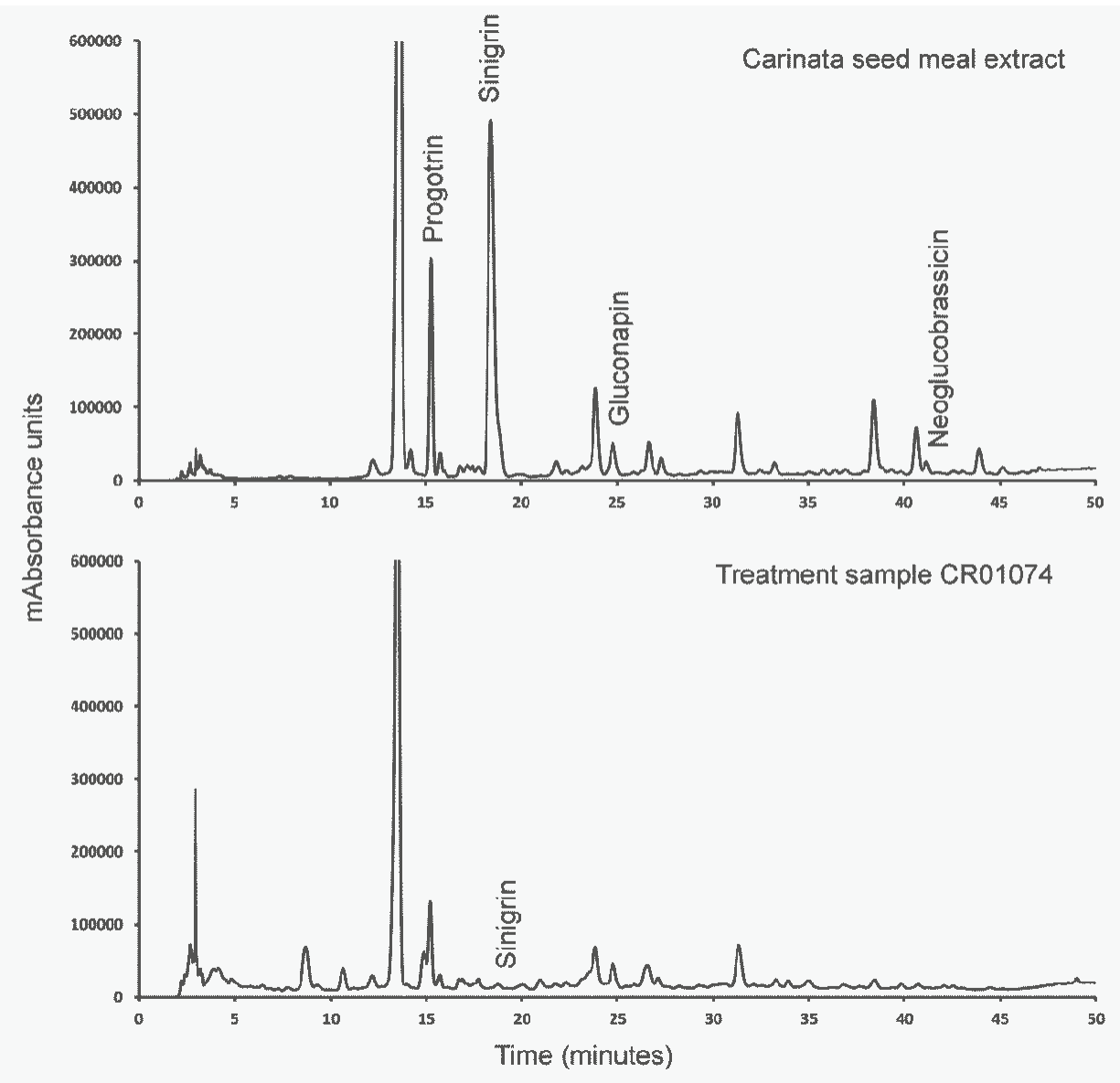

Figure 1: GC-MS chromatograms with GLS peaks from defatted carinata seed meal (A) and HE carinata seed meal fermented with M. circinelloides (B).
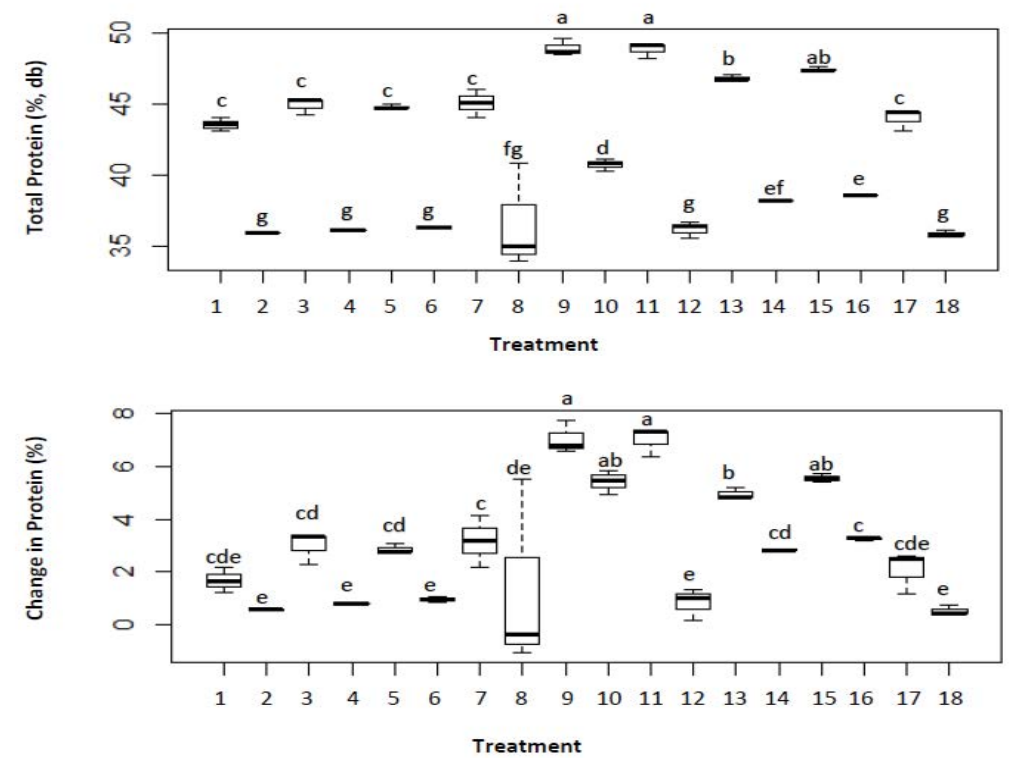

1=A. pullulans $23 \mathrm{HE} ; 2=A$. pullulans $23 \mathrm{CP} ; 3=A$. pullulans $58 \mathrm{HE} ; 4=A$. pullulans $58 \mathrm{CP} ; 5=R$. microsporus $\mathrm{HE} ; 6=R$. microsporus $\mathrm{CP} ; 7=F$. venenatum $\mathrm{HE} ; 8=F$. venenatum $\mathrm{CP} ; 9=N$. crassa $\mathrm{HE} ; 10=N$. crassa $\mathrm{CP} ; 11=P$. variotti $\mathrm{HE} ; 12=P$. variotti $\mathrm{CP} ; 13=M$. circinelloides $\mathrm{HE} ; 14=M$. circinelloides $\mathrm{CP} ; 15=T$. reesei $\mathrm{HE} ; 16=T$. reesei $\mathrm{CP} ; 17=P$. kudriavzevii $\mathrm{HE} ; 18=P$. kudriavzevii $\mathrm{CP}$

Figure 2: Comparison of end-point total protein content (\%, db) (A), and change in protein content (\%) during a trial (B). Different lower case letters annotate a statistical difference occurred among the means determined by a Tukey's test. 

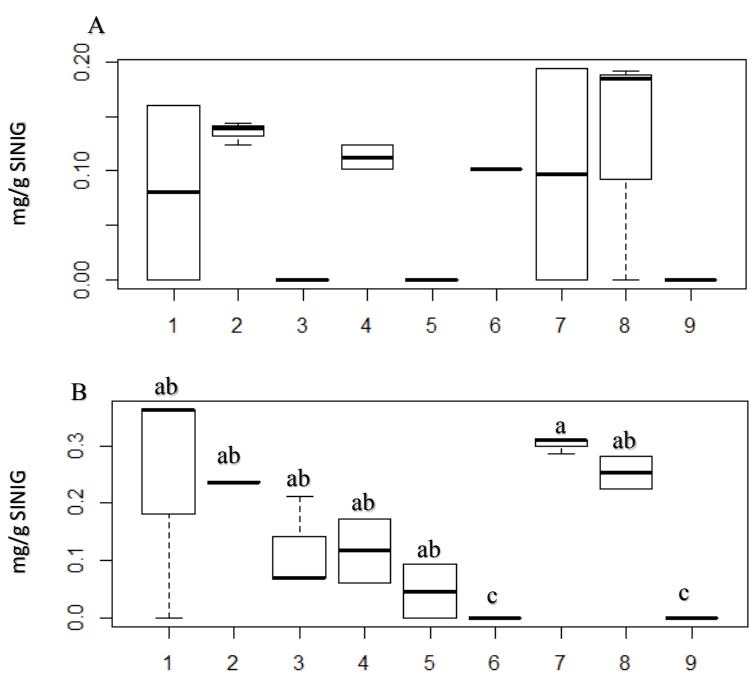

$$
\begin{aligned}
& 1=A . \text { pullulans } 23 \\
& 2=A . \text { pullulans } 58 \\
& 3=T . \text { reesei } \\
& 4=F . \text { venenatum } \\
& 5=P . \text { variotti } \\
& 6=R . \text { microsporus } \\
& 7=M . \text { circinelloides } \\
& 8=P . \text { kudriavzevii } \\
& 9=N . \text { crassa }
\end{aligned}
$$

1=A. pullulans 23; 2=A. pullulans 58; 3=T. reesei; 4=F. venenatum; 5=P. variotti; $6=R$. microspores; $7=M$. circinelloides; 8=P. $k$ udriavzevii ; 9=N. crassa

Figure 3: Comparison of end-point sinigrin content in fungal fermentations in cold-pressed $(A)$ and hexane extracted (B) carinata meal. Different lower case letters annotate a statistical difference occurred among the means determined by a Tukey's test. No statistical differences were detected among the means in Fig. $3 A$.

\section{of carinata meal.}

Carinata contains high concentrations of GLS, and SINIG constitutes virtually all of the GLS in the oilseed. GLS are antinutritional compounds that decrease the economic value of feeds, thus reducing the concentration of GLS in carinata meal would have a substantially positive impact. Advancements in breeding techniques have resulted in the development of carinata varieties with reduced concentrations of GLS, however, the seeds still contain enough GLS (80 $\mu \mathrm{M} / \mathrm{g}$ ) to have a negative economic impact [26]. The GLS content of the HE and CP carinata meal used in this study was $16.2(45.2 \mu \mathrm{M} / \mathrm{g})$ and $15.3(42.7 \mu \mathrm{M} / \mathrm{g}) \mathrm{mg}$ SINIG/g, respectively. Sinigrin was the only GLS quantitated via GC-MS in these trials. Both the pretreated meals contained substantially less GLS than carinata [26]. However, neither of these meals could be included in the animal diet without decreasing the GLS content, as feed must contain less than $11 \mu \mathrm{M} / \mathrm{g}$ GLS [8].

Since microbial fermentation has been shown to be an effective processing method to degrade GLS in oilseed meals [10,25], the efficacy of various fungal strains to degrade GLS of carinata meals (HE and CP) were evaluated during SSFs (Figure 3). Figure $3 \mathrm{~A}$ shows the comparison of end-point SINIG content in fungal fermentations of CP meal. A oneway ANOVA detected no significant differences among the means in any fungal fermentation treatment with CP carinata meal. Mean GLS values ranged from $0-0.19 \mathrm{mg} / \mathrm{g}$ SINIG, which is equivalent to $0-0.53$ $\mu \mathrm{M} / \mathrm{g}$ SINIG. Cold pressed carinata meal fermented with N. crassa, $P$. variotti and T. reesei contained no SINIG at end of the fermentation period.

The end-point SINIG results from fermented HE carinata meal is shown in Figure 3B. A one-way ANOVA did detect differences in these trials, thus a Tukey's test was performed to determine among which treatments a statistical difference occurred. R. microsporus and $N$. crass $a$ yielded significantly less SINIG than all other treatments $(0$ $\mathrm{mg} / \mathrm{g}$ SINIG). $M$. circinelloides yielded significantly more SINIG than all other treatments evaluated in this study $(0.30 \mathrm{mg} / \mathrm{g}$ SINIG). Figures $3 \mathrm{~A}$ and $3 \mathrm{~B}$ also show that from a SINIG standpoint, there is no clear advantage to using $\mathrm{CP}$ or $\mathrm{HE}$ carinata meal. Although previous studies have reported reductions of GLS after microbial fermentation of oilseed meals, the complete reduction of GLS achieved in this study shows that carinata meal has great potential to be utilized for feed application [10]. In this study, N. crassa SSF of HE extracted carinata meal yielded a GLS content of $0 \mathrm{mg} / \mathrm{g}$, and no other treatments evaluated in this study had a significantly higher end-point total protein content $[\sim 50 \%,(\mathrm{db})]$. Thus, this treatment is the preferred treatment evaluated in this study and will be the focus of future research conducted by our research group.

A future direction of this work is to evaluate mycotoxins produced by $N$. crassa and to determine if any deleterious effects on the nutritional value of the feed from these toxins. Fungi produce a vast array of small bioactive compounds termed secondary metabolites, including antibiotics, pigments, and mycotoxins [27]. Mycotoxins are toxic fungal secondary metabolites common in agricultural products [28]. N. crassa has not been shown to possess secondary metabolism, except for carotenoids and melanin. However, the genome contains several putative genes for secondary metabolite production [27]. It is promising that $N$. crassa is not known to produce mycotoxins, but it would be worthwhile to investigate further.

\section{Conclusion}

In this study, several fungal strains were evaluated for their ability to increase protein content and metabolize GLS during SSFs of carinata 
Citation: JJ Simon, SA Wootton, TJ Johnson, B Karki, JD Zahler, et al. (2017) Solid State Fermentation of Carinata (Brassica carinata) Meal Using Various Fungal Strains to Produce a Protein-Rich Product for Feed Application. J Microb Biochem Technol 9:577-582. doi: 10.4172/19485948.1000344

meal. The goal of this work was to improve the nutritional composition of $\mathrm{HE}$ and $\mathrm{CP}$ carinata meal. We determined that fungal fermentations of HE carinata meal consistently yielded higher end-point protein contents, regardless of the fungal strain utilized. Of the fungal strains evaluated in this study, $N$. crassa and $P$. variotti yielded significantly more end-point protein than all the other fungal strains during SSFs of HE carinata meal. Regardless of the pretreatment method (HE or $\mathrm{CP}$ ), carinata meal fermented by $N$. crassa resulted in the complete reduction of GLS (0 $\mathrm{mg} / \mathrm{g}$ SINIG). Solid state fermentation of $\mathrm{HE}$ carinata meal utilizing $N$. crassa yielded an end-point total protein content of $\sim 50 \%,(\mathrm{db})$ and a GLS content of $0 \mathrm{mg} / \mathrm{g}$ GLS, thus was the most promising treatment evaluated. This study provides strong evidence that HE carinata meal fermented with $N$. crassa has potential for feed application.

\section{Acknowledgement}

Funding support for this study was provided by the Oilseeds Council of South Dakota and Agricultural Experimentation Station of South Dakota State University.

\section{References}

1. Gibbons W, Croat J (2016) High quality protein concentrate from canola meal. US Patent: US20160242435 A1.

2. Bootsma JA, Gibbons WR, Brown ML (2014) Solid state fermentation systems and process for producing high-quality protein concentrate and lipids. US Patent: US20150044356 A1.

3. Cardone M, Mazzoncini M, Menini S, Rocco V, Senatore, A, et al. (2003) Brassica carinata as an alternative oil crop for the production of biodiese in Italy: Agronomic evaluation, fuel production by transesterification and characterization. Biomass and Bioenergy 25: 623-636.

4. Rakow G (2003) The potential of Brassica juncea, B. carinata and Sinapis alba as new oilseed crops in Canada. Proceeding of the 11th International Rapeseed Congress.

5. Pedroche J, Yust MM, Lqari H, Girón-Calle J, Alaiz M et al. (2004) Brassica carinata protein isolates: chemical composition, protein characterization and improvement of functional properties by protein hydrolysis. Food Chem 88: 337-346.

6. Demain AL, Vaishnav $P$ (2009) Production of recombinant proteins by microbes and higher organisms. Biotechnol Adv 27: 297-306.

7. Nicoletti M (2016) Microalgae nutraceuticals. Foods 5: 54.

8. Tripathi M, Mishra A (2007) GLSs in animal nutrition: A review. Animal Feed Science and Technology 132: 1-27.

9. Chen S, Andreasson E (2001) Update on GLS metabolism and transport. Plant Physiol Biochem 39: 743-758.

10. Croat JR, Gibbons WR, Berhow M, Karki B, Muthukumarappan K (2016) Conversion of canola meal into a high-protein feed additive via solid-state fungal incubation process. J Am Oil Chem Soc 93: 499-507.
11. Newkirk R, (2009) Canola meal feed industry guide. Canola Council of Canada 4th Edition.

12. Burel C, Boujard T, Escaffre AM, Kaushik SJ, Boeuf G et al. (2000) Dietary low-GLS rapeseed meal affects thyroid status and nutrient utilization in rainbow trout (Oncorhynchus mykiss). Br J Nutr 83: 653-664.

13. Moloney A, Woods V, Crowley J (1998) A note on the nutritive value of camelina meal for beef cattle. Irish Journal of Agricultural and Food Research 37: 243-247.

14. Pandey A, Selvakumar P, Soccol CR, Nigam P (1999) Solid state fermentation for the production of industrial enzymes. Curr Sci 77: 149-162.

15. Pandey A, Soccol CR, Mitchell D (2000) New developments in solid state fermentation: Bioprocesses and products. Process Biochemistry 35: 1153-1169.

16. Couto SR, Sanromán MA (2006) Application of solid-state fermentation to food industry - A review. J Food Eng 76: 291-302.

17. Smits J, Knol W, Bol J (1993) GLS degradation by Aspergillus clavatus and Fusarium oxysporum in liquid and solid-state fermentation. Appl Microbio Biotechnol 38: 696-701.

18. AACC International. Approved methods of analysis, 11th Ed. Method 44-20.01. Moisture-ASBC Air-Oven Method. AACC International.

19. Croat JR, Gibbons WR, Berhow M, Karki B, Muthukumarrapan K (2016) Enhancing the nutritional value of canola (Brassica napus) meal using a submerged fungal incubation process. J Food Res 5: 1.

20. Betz J, Fox W (1994) High-performance liquid chromatographic determination of GLSs in Brassica vegetables. In: Food Phytochemicals for Cancer Prevention pp. 181-186. ACS Publications.

21. Berhow MA, Polat U, Glinski JA, Glensk M, Vaughn SF et al. (2013) Optimized analysis and quantification of GLSs from Camelina sativa seeds by reversephase liquid chromatography. Ind Crops Prod 43: 119-125.

22. De Mendiburu F (2014) Agricolae: statistical procedures for agricultural research. $R$ package version, 2014

23. R Core Team (2013) R: A language and environment for statistical computing.

24. Bednarek P, Piślewska-Bednarek M, Svatoš A, Schneider B, Doubský J et al. (2009) A GLS metabolism pathway in living plant cells mediates broadspectrum antifungal defense. Science 323: 101-106.

25. Hölker U, Höfer M., Lenz J (2004) Biotechnological advantages of laboratoryscale solid-state fermentation with fungi. Appl Microbiol Biotechnol 64: 175-186.

26. Barro F, Fernández-Escobar J, De la Vega M, Martín A (2003) Modification of GLS and erucic acid contents in doubled haploid lines of Brassica carinata by UV treatment of isolated microspores. Euphytica 129: 1-6.

27. Galagan JE, Calvo SE, Borkovich KA, Selker EU, Read ND et al. (2003) The genome sequence of the filamentous fungus Neurospora crassa. Nature 422 859-868.

28. Krska R, Sulyok M, Berthiller F, Schuhmacher R (2017) Mycotoxin testing: From multi-toxin analysis to metabolomics. JSM Mycotoxins 67: 11-16.

29. O'Donnell K (2000) Molecular phylogeny of the Nectria haematococcaFusarium solani species complex. 92: 919-938. 